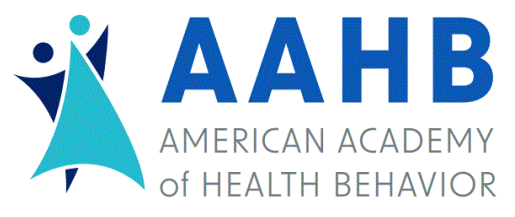

\section{Health Behavior Research}

Volume 1 | Number 1

Article 5

October 2017

Reflections on 15 years in the global tobacco trenches

Kenneth D. Ward

University of Memphis, kdward@memphis.edu

Follow this and additional works at: https://newprairiepress.org/hbr

Part of the Epidemiology Commons, and the Psychology Commons

(c) (i) (9)

This work is licensed under a Creative Commons Attribution-Noncommercial 4.0 License

\section{Recommended Citation}

Ward, Kenneth D. (2017) "Reflections on 15 years in the global tobacco trenches," Health Behavior Research: Vol. 1: No. 1. https://doi.org/10.4148/2572-1836.1007

This Commentary is brought to you for free and open access by New Prairie Press. It has been accepted for inclusion in Health Behavior Research by an authorized administrator of New Prairie Press. For more information, please contact cads@k-state.edu. 


\title{
Reflections on 15 years in the global tobacco trenches
}

\begin{abstract}
This paper is based on my 2017 Research Laureate Presentation at the annual scientific meeting of the American Academy of Health Behavior in Tucson, Arizona. It provides a brief overview of the history of the smoking epidemic, and describes my work in global tobacco control, focusing on my experiences over the last 15 years as a co-founder and intervention director of the Syrian Center for Tobacco Studies (SCTS) in Aleppo, Syria. The SCTS is an NIH-funded research center that draws on a broad range of complementary expertise and resources from developed and developing nations to address the tobacco epidemic in the Arab World. The SCTS strives to serve as a model of scientific excellence and commitment to the health of people in the Middle East and beyond. Major research streams using qualitative, epidemiological, clinical lab, and intervention methodologies are reviewed, along with some of the successes and challenges encountered since the SCTS's founding.
\end{abstract}

\section{Keywords}

Tobacco control, smoking cessation, Eastern Mediterranean Region, waterpipe 


\title{
Reflections on 15 Years in the Global Tobacco Trenches
}

\author{
Kenneth D. Ward, PhD, FAAHB*
}

\begin{abstract}
This paper is based on my 2017 Research Laureate Presentation at the Annual Scientific Meeting of the American Academy of Health Behavior in Tucson, Arizona. It provides a brief overview of the history of the smoking epidemic, and describes my work in global tobacco control, focusing on my experiences over the last 15 years as a co-founder and intervention director of the Syrian Center for Tobacco Studies (SCTS) in Aleppo, Syria. The SCTS is an NIH-funded research center that draws on a broad range of complementary expertise and resources from developed and developing nations to address the tobacco epidemic in the Arab World. The SCTS strives to serve as a model of scientific excellence and commitment to the health of people in the Middle East and beyond. Major research streams using qualitative, epidemiological, clinical lab, and intervention methodologies are reviewed, along with some of the successes and challenges encountered since the SCTS's founding.
\end{abstract}

*Corresponding author can be reached at: kdward@memphis.edu

The American Academy of Health Behavior (AAHB) has been my professional home for many years, and it is an honor to be named the 2017 Research Laureate. My work focuses on preventing chronic disease, and I have “dabbled” in understanding behavioral determinants and intervention approaches to conditions such as metabolic syndrome and heart disease ${ }^{1-7}$ and osteoporosis, $^{8-13}$ but my true passion throughout my career has been tobacco control, especially improving methods to help smokers quit.

The initial spark for this interest came from growing up in a family of inveterate smokers. We study what we're bad at, as the old saying goes. I watched many family members - my father, his four siblings, and more recently my brother - struggle mightily, and too often, unsuccessfully, to quit. Many of them died much too young from the inevitable consequences of smoking - lung cancer, chronic obstructive pulmonary disease, and heart disease.

I have been fortunate to have superb mentors throughout my career, and as an undergraduate at Brown University in the 1980s, my earliest mentors showed me that I could make tobacco control a career. Ray Niaura and David Abrams - two AAHB Research Laureates - were my first inspirations for this career. Ray was a member of my undergraduate honors thesis committee. He and David gave me my first job in this field, working as a research assistant on cue reactivity studies in smokers. In the interest of full disclosure, I'll admit that I was a social smoker back in those days and particularly enjoyed one job duty: In those cue reactivity studies, I was responsible for hooking smokers up to psychophysiological monitoring equipment, and after I got them comfortably situated in a small lab room, I would stroll in, take out a pack of 
their preferred cigarette brand, and smoke it in front of them. All for science, mind you, but I received some personal gratification as well.

I took a job in the late 1980s at the Boston Veterans Administration Outpatient Clinic, working for Arthur J. (“Jim”) Garvey, who despite being a quintessentially grumbly Bostonian, is one of the kindest people I ever met. I learned a lot from him, especially about being modest, ethical, diligent, respectful, and generous. Jim was always willing to share the credit with his employees and colleagues. His knack for treating everyone, especially underlings, as colleagues was a powerful lesson that I've tried to emulate. Working for Jim, I coordinated a cohort study to learn about psychological and physiological changes experienced during unaided cessation. ${ }^{14-16}$ Quitting on one's own without help was then, and still is (despite treatment advances), the most common way people quit smoking. What an incredible learning experience it was to interview dozens of smokers multiple times over the course of their first year after a quit attempt to learn about their successes and challenges.

Later, other important mentors included Scott Weiss, a Harvard pulmonologist and epidemiologist from whom I learned the ins and outs of conducting large-scale studies in chronic disease epidemiology. ${ }^{5-7}$ I moved to Memphis in 1993 to work on my PhD under Bob Klesges. Bob is a talented and successful smoking cessation trialist, and I learned much from him about how to write grants and treat tobacco addiction. ${ }^{17-21}$ We need mentors throughout our careers, and our own Elbert Glover has been a wonderful confidante and counselor as I have established myself as a health behavior researcher, sharing his wisdom with me through the tenure process, job searches, and academic administration positions. I owe a debt of gratitude to all these people as well as the many bosses, colleagues, and students I've worked with over the years.

\section{Scope of the Smoking Problem}

The twentieth century has been called "The cigarette century."22 Originally a small niche product in the latter part of the $19^{\text {th }}$ century, cigarette sales began to skyrocket in the early 1900 s and quickly replaced cigars, pipes, and chew as the preferred tobacco use method. ${ }^{22}$ The cigarette century was made possible by James Bonsack's invention of a cigarette rolling machine in $1880,{ }^{23}$ which immediately raised output from the four cigarettes per minute that an experienced hand roller could produce, to 200 cigarettes per minute by even the earliest versions of Bonsack's machine. Further advancements both in manufacturing and marketing led to rapid increases in cigarette use during the first half of the $20^{\text {th }}$ century. At the zenith of smoking in the United States in 1965, approximately $42 \%$ of U.S. adults smoked, including more than half of men and one-third of women. ${ }^{24}$ Tobacco use in the United States began to decline after the publication of the first Surgeon General's Report on Smoking and Health, ${ }^{25}$ which comprehensively laid out the evidence of smoking's causal role in lung cancer and other diseases. Smoking continued to decline in the United States as more adults quit and fewer children began smoking. This progress occurred gradually, despite tobacco industry interference at every turn, and was exacted by advocacy and numerous policy changes - advertising bans, youth access restriction, increased taxation, and the development and widespread dissemination of behavioral and pharmacological cessation treatments ${ }^{22,23}$ (See Figure 1). Today, smoking rates are below $20 \%$ for both men and women in the United States, ${ }^{26}$ causing tobacco control to be hailed as the single greatest public health achievement in the United States of the $20^{\text {th }}$ century. ${ }^{27-}$ 29 
Figure 1. Adult per capita cigarette consumption and major smoking and health events, United States, 1900-2012 (from U.S. Department of Health and Human Services, The Health Consequences of Smoking-50 Years of Progress: a report of the Surgeon General, Centers for Disease Control and Prevention, National Center for Chronic Disease Prevention and Health Promotion, and Office of Smoking and Health)

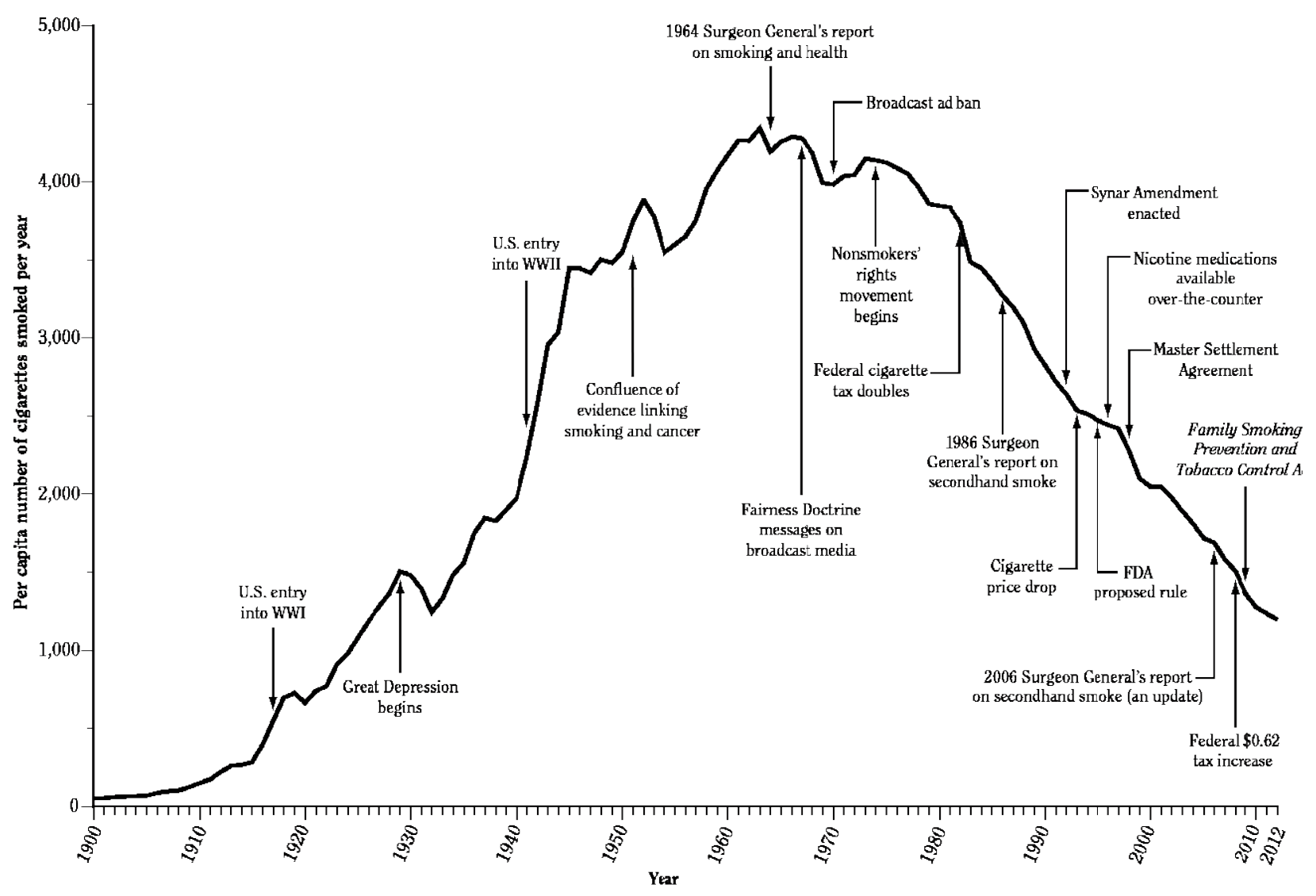

Sources Adapted from Waner 1985 with permission from Masachusetts Medica Society, O1985; U.S Department of Heath and Human Services 1989, Creek et d. 1994; U.S Department of Agriculture 2000; U.S. Census Bureal 2013; U.S. Department of the Treasury 2013.

Adults $\geq 18$ years of age $a$ reported annually by the Census Bureal.

But as all health behavior researchers know, the story isn't entirely rosy. Smoking is still the greatest cause of premature morbidity and mortality in the United States, killing approximately 480,000 people each year. ${ }^{30}$ Even worse, it has become a global epidemic. Currently, more than a billion people around the world smoke. Nearly five and a half million of them die each year prematurely due to smoking, and a significant shift has occurred, such that in the near future the majority of deaths will occur in developing countries. While smoking killed 100 million people during the $20^{\text {th }}$ century, it's expected to kill ten times that number -1 billion - during the current century. ${ }^{31}$

As an assistant professor starting a career in tobacco control in the late 1990s, my interest in global tobacco control was sparked by the disheartening realization that we were engaged in a kind of whack-a-mole game: As we reduced tobacco use in the United States and other highincome countries, it accelerated in the developing world, with multinational tobacco companies rushing to open new markets and create new customers faster than our prevention and cessation efforts could stop this. Clearly, we are losing the game, with global tobacco use increasing 
exponentially and 5.8 trillion cigarettes smoked around the world in $2014 .^{32}$ The complicit tobacco industry/government strategy was expressed eloquently in 1990 by U.S. Vice President Dan Quayle, who famously said: “Tobacco exports should be expanded aggressively, because Americans are smoking less.”33

\section{Establishment of the Syrian Center for Tobacco Studies}

My first opportunity to become involved in global tobacco control came in June, 2001, when the National Institutes of Health announced a new funding opportunity to help low and middle-income countries build infrastructure for tobacco control research. The International Tobacco Health and Capacity-Building Program (ITHCBP; RFA-TW-02-005) focused on novel and regionally relevant work, emphasizing capacity building, training of scientists, and international cooperation to increase the ability of developing nations to engage in effective tobacco control research. ${ }^{34}$ The ITHCBP has been a sizeable commitment for NIH; they allocated close to $\$ 4$ million for this first round and subsequently funded two more rounds, with a fourth round now about to be launched (RFA-TW-16-003).

I wanted to respond to this announcement but did not have international collaborators. Then one day that summer, an email appeared on the listserv of the Society for Research on Nicotine and Tobacco (SRNT) from a Syrian researcher by the name of Wasim Maziak, looking for collaborators for this funding opportunity.

As an aside, it is worth noting that Wasim is the hero of my story. He is an exceptionally bright, hard-working individual, and his journey reminds me how fortunate we are in the United States to have the opportunity to pursue research careers. Doing so is difficult - the work is tough, jobs are not plentiful, and funding is scarce. But if we want a research career, and are willing to work hard, we have an excellent chance of succeeding. This was not the case in Syria, Wasim's homeland. He attended medical school in his hometown at the University of Aleppo. Syria had no doctoral training programs, so when Wasim decided he wanted to pursue a research career, he learned Russian and moved to Kiev to obtain a PhD in allergy/immunology. He then returned to Aleppo and opened a private medical practice, took a clinical faculty position at the medical school, and began to do research in his free time. With no culture of research at his university and no funding, he began collecting data on tobacco use on nights and weekends, recruiting his brother and wife, both physicians, as his research assistants. They were the first to characterize tobacco use in Syria and published several very good epidemiological studies about smoking prevalence and determinants among university students, low-income women, physicians, and high school students. ${ }^{35}$

With no opportunities for a research career in Syria, Wasim and his family left, and he took post-doctoral positions in Atlanta, then London, then Muenster, hoping for an opportunity to return to his homeland eventually. Wasim was working as a post-doc at the University of Muenster's Institute of Epidemiology and Social Medicine when he saw the ITHCBP funding opportunity announcement and sent an email on the SRNT listserv to which both Tom Eissenberg, then an assistant professor of psychology at Virginia Commonwealth University, and I responded.

Wasim, Tom, and I started an email conversation in July of 2001 and began brainstorming how the three of us could work together. Developing a collaboration and writing a grant with strangers, entirely via email, may not seem so unusual nowadays, but in 2001 it seemed quite innovative! It all nearly came to a crashing end only a couple of months later. We 
had arranged for Tom to spend a few days in Memphis to work on the grant. This would have been the first time that any of us had met in person. However, Tom never made it. His morning flight to Memphis on September $11^{\text {th }}$ never left Richmond due to the terrorist attacks underway in New York, Washington DC, and Pennsylvania. We were stunned, like everyone, and put aside the grant and spent a couple of weeks figuring out how to regroup. It seemed very unlikely after this tragedy that the U.S. government would fund research in the Middle East, particularly in Syria, a country which was on the U.S. government's list of state sponsors of terrorism. NIH's Fogarty International Center was (and continues to be) very supportive, and encouraged us not to give up. So, we got back to work and were thrilled when our grant, "Establishment of the Syrian Center for Tobacco Studies,” was funded (R01 TW05962).

The Syrian Center for Tobacco Studies (SCTS) (www.scts-sy.org) was opened in Aleppo, located in northern Syria near the Turkish border, in 2002. Aleppo is an ancient city, on the famed "Silk Road" network of trade routes between East and West, and considered to be the oldest continually inhabited city in the world, going back as many as 8000 years. Until the Syrian Civil War began in 2011, Aleppo was a thriving industrial and commercial center and was Syria's largest city with a population of more than two million. Our work began nine years before the war and has continued in spite of it, as discussed below.

\section{Qualitative, Clinical Lab, and Epidemiological Studies}

The initial goals of the SCTS were to train Syrian researchers and develop capacity in the Eastern Mediterranean Region (EMR) to conduct epidemiologic, clinical laboratory, and cessation intervention research related to local tobacco products. While cigarette use is common in Syria and throughout the EMR, an emerging and understudied local tobacco product that attracted our attention was waterpipe. Waterpipe, known colloquially by such names as hookah, shisha, and narghile, is a centuries-old tobacco use method, in which tobacco is heated, usually with charcoal, and its smoke is passed through water before inhalation ${ }^{36}$ (see Figure 2). Waterpipe tobacco smoking (WTS) is thought to have originated on the Indian sub-continent during the $16^{\text {th }}$ century and found its way over the next century to Persia, Turkey, and the EMR. $^{36}$

Figure 2. Waterpipe Apparatus and Schematic

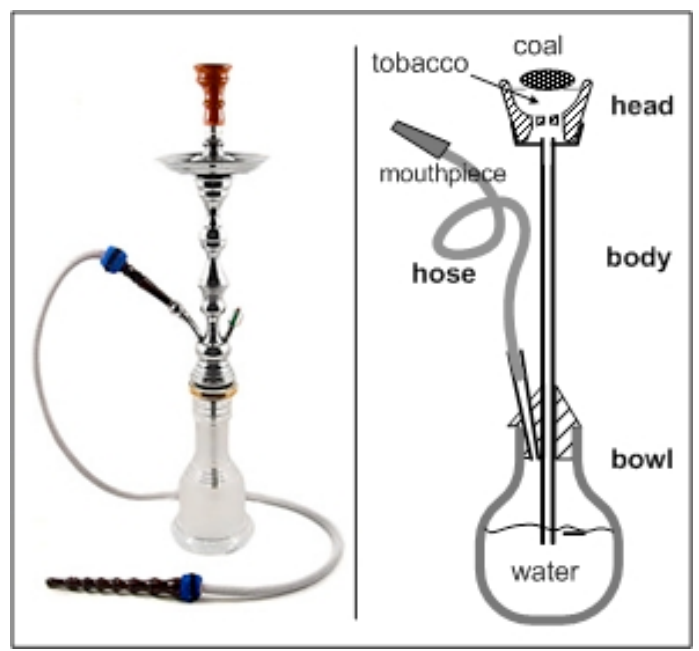


By the end of the $20^{\text {th }}$ century, the popularity of WTS had dwindled, and it was favored mainly by older Arab men who smoked it socially in cafes. WTS was so rare that national and international surveys of tobacco use in the Middle East failed to inquire about it. Its popularity began to re-emerge, however, in the 1990s, fueled by several factors. The chief contributor was the invention of maassel (or Mu'essel; "asal” means honey in Arabic), a tobacco mix flavored with molasses or fruit. Maassel is moist (making it easier to use than older and drier types of waterpipe tobacco). The passage of smoke through water makes it very smooth to inhale, unlike the harshness of cigarettes. And it is very fragrant. These characteristics are very appealing to young people, ${ }^{37,38}$ who have been at the epicenter of a global spread of WTS. ${ }^{39,40}$ Despite WTS being associated with multiple adverse health effects, ${ }^{41,42}$ there are widespread misperceptions among adolescents and young adult users that it is safe, or at least safer than cigarettes. ${ }^{38,40,43,44}$ Other contributors to the new popularity of WTS were a growing café culture in the Middle East, expanding internet availability, and increasing globalization that made WTS a global phenomenon in just two decades. ${ }^{36,39}$

To better understand the use of waterpipe and cigarettes in Syria, and to guide us in accessing relevant populations, we began our work with qualitative studies, using key informant interviews and focus groups. ${ }^{45,46}$ Next, clinical lab work was carried out to understand how local tobacco products were used. One stream of this research demonstrated WTS's dependence potential, showing that smokers inhaled substantial amounts of toxicants, including nicotine, and experienced withdrawal symptoms during abstinence that were relieved by smoking. ${ }^{47-49}$

Simultaneously, we carried out a series of epidemiological studies, including the country's first population-based household surveys, to understand the patterns and determinants of tobacco use and cessation in Aleppo. In 2004, the Aleppo Household Survey found very high rates of smoking, with $57 \%$ of men and $17 \%$ of women currently smoking cigarettes, and $20 \%$ and $5 \%$, respectively, currently smoking waterpipe. ${ }^{50}$ Consistent with the notion that waterpipe use was a re-emerging strain in a global tobacco epidemic, our survey work indicated that the vast majority of waterpipe users, regardless of age, had initiated use after 1990, with use continuing to escalate during the first decade of the $21^{\text {st }}$ century. ${ }^{51}$ Survey work also indicated that while there was considerable interest in quitting smoking, quit rates were very low. ${ }^{50,52}$ For example, only $15 \%$ of those who had ever smoked cigarettes had quit, which is half of the prevalence of quitting among U.S. smokers. ${ }^{26}$ Consistent with our clinical lab data showing that waterpipe delivered large amounts of nicotine and produced withdrawal symptoms, ${ }^{47-49}$ survey work indicated that many waterpipe users exhibited dependence symptoms. Waterpipe users often escalated the frequency of their use over time (consistent with tolerance), considered themselves to be "hooked," and had difficulty quitting. ${ }^{43,52}$ Because WTS is not as "portable" as cigarette smoking, we found that heavy users were likely to engage in behavioral adaptation to ensure access to waterpipe (eg, owning one's waterpipe, selecting restaurants based on whether waterpipe is available, and smoking mainly alone and/or at home). ${ }^{53,54}$

\section{Tobacco Intervention Trials}

The qualitative, clinical lab, and epidemiological studies we conducted in Syria provided the foundation for the development of smoking cessation interventions, which is my primary research interest. This foundation was essential to our work because Syria had no infrastructure for smoking cessation. Medical and nursing students received no training in smoking cessation; 
smoking by physicians and nurses was prevalent and made them reluctant to address their patients' smoking; there were no clinical practice guidelines, and neither specialty cessation clinics nor pharmacotherapy such as nicotine replacement or Bupropion were available. ${ }^{55,56}$ There also was no expertise in developing and scientifically evaluating cessation interventions.

Our efforts to build evidence-based tobacco treatment in Syria were detailed in a recent paper. ${ }^{56}$ We began by using both in-country instruction and distance learning to train a small core group of physicians to deliver cessation interventions and to conduct randomized controlled trials to evaluate them. Our first effort to demonstrate our ability to intervene and evaluate was a pilot trial of 50 cigarette smokers who wanted to quit. ${ }^{57}$ Smokers were randomized to receive either brief (single session) or intensive (four sessions plus six follow up phone calls) free, behavioral cessation counseling delivered by a physician. Seven-day point prevalent abstinence, which was confirmed biochemically, at three months post-cessation was low for both the brief and intensive groups (16\% and 4\%, respectively, $p=.34$ ). Nicotine dependence predicted failure to quit, and important perceived barriers to quitting were believing oneself to be dependent on nicotine, not having access to cessation pharmacotherapy, poor social support, and smoking waterpipe. Our process evaluation indicated that participants were satisfied with the care they received and the treatment program in general, and gave us valuable information on how to modify the protocol to improve adherence and efficacy. ${ }^{56,57}$

This pilot study demonstrated our ability to train physicians to competently deliver evidence-based cessation treatments and conduct rigorous evaluations of treatment programs using randomized controlled trial methodology. Our next undertaking was to carry out an effectiveness trial to determine whether cessation interventions could be successfully integrated into Syrian primary care clinics. As noted above, our pilot study did not offer pharmacotherapy. This was problematic not only because smokers were highly nicotine dependent, but also because of a cultural expectation that medication should be received during a medical encounter. As a result, many participants in our pilot study were demoralized about receiving only behavioral treatment. While there was convincing evidence from the United States and other high-income countries that nicotine replacement products and Bupropion boosted quit rates, ${ }^{58}$ these products were not available in Syria. In early 2004, as we planned this work, we met with Syria’s Minister of Health, Professor M. Eyad Chatty, and asked about the possibility of government-operated primary care clinics providing cessation medication. To offer these would be an expensive undertaking, and the health minister told us he wanted to see efficacy data collected in Syria as a first step in making these medications available. Given the large number of cessation pharmacotherapy trials already conducted in other countries, undertaking another one to replicate a well-known effect was not very interesting to us. We decided, however, that doing so was a political necessity if we were to have any chance of making effective cessation treatment available in Syria.

With these marching orders, our next study was a multi-site, two-arm, randomized, placebo-controlled trial to test the effectiveness of nicotine patch as adjunctive treatment with behavioral counseling in primary care settings. ${ }^{59-62}$ Four clinics were selected and clinic staffs were trained by physician staff members of the SCTS to make system-level changes to support cessation efforts (eg, having receptionists document the smoking status of all patients, and training physicians to briefly assess their patients' smoking status and willingness to make a quit attempt). Two hundred and sixty-nine adult primary care patients who were smokers were enrolled and randomized to receive six weeks of treatment with nicotine or placebo patch. All participants received behavioral counseling from a specially trained primary care physician in the 
clinic. Primary endpoints were biochemically confirmed prolonged abstinence (no smoking whatsoever after a 2-week grace period) through 12 months post-cessation (see Figure 3). Much to our surprise, nicotine patch did not boost quit rates over and above what could be achieved by behavioral counseling alone, in contrast to an extensive literature from high-income countries. ${ }^{58,63,64}$ The proportion of patients in the nicotine and placebo groups with prolonged abstinence was $21.6 \%$ and $20.0 \%$, respectively, at end of treatment, $13.4 \%$ and $14.1 \%$ at 6 months, and $12.7 \%$ and $11.9 \%$ at 12 months (all $p$-values $>.75$ ). The lack of a treatment effect occurred despite excellent retention and adherence to medication use and behavioral counseling, and expected decreases in withdrawal symptomatology among the nicotine group. These results need to be followed up, but this first "real world" cessation pharmacotherapy trial in a lowincome country setting suggests that medication, which often is very expensive or not available, may not offer a benefit beyond what can be achieved by behavioral counseling.

Figure 3. CONSORT diagram for a multi-site, two-arm, randomized, placebo-controlled trial to test the effectiveness of nicotine patch as adjunctive treatment with behavioral counseling in primary care setting; reprinted from (reprinted from Ward KD, et al. Addiction. 2013;108(2):394-403).

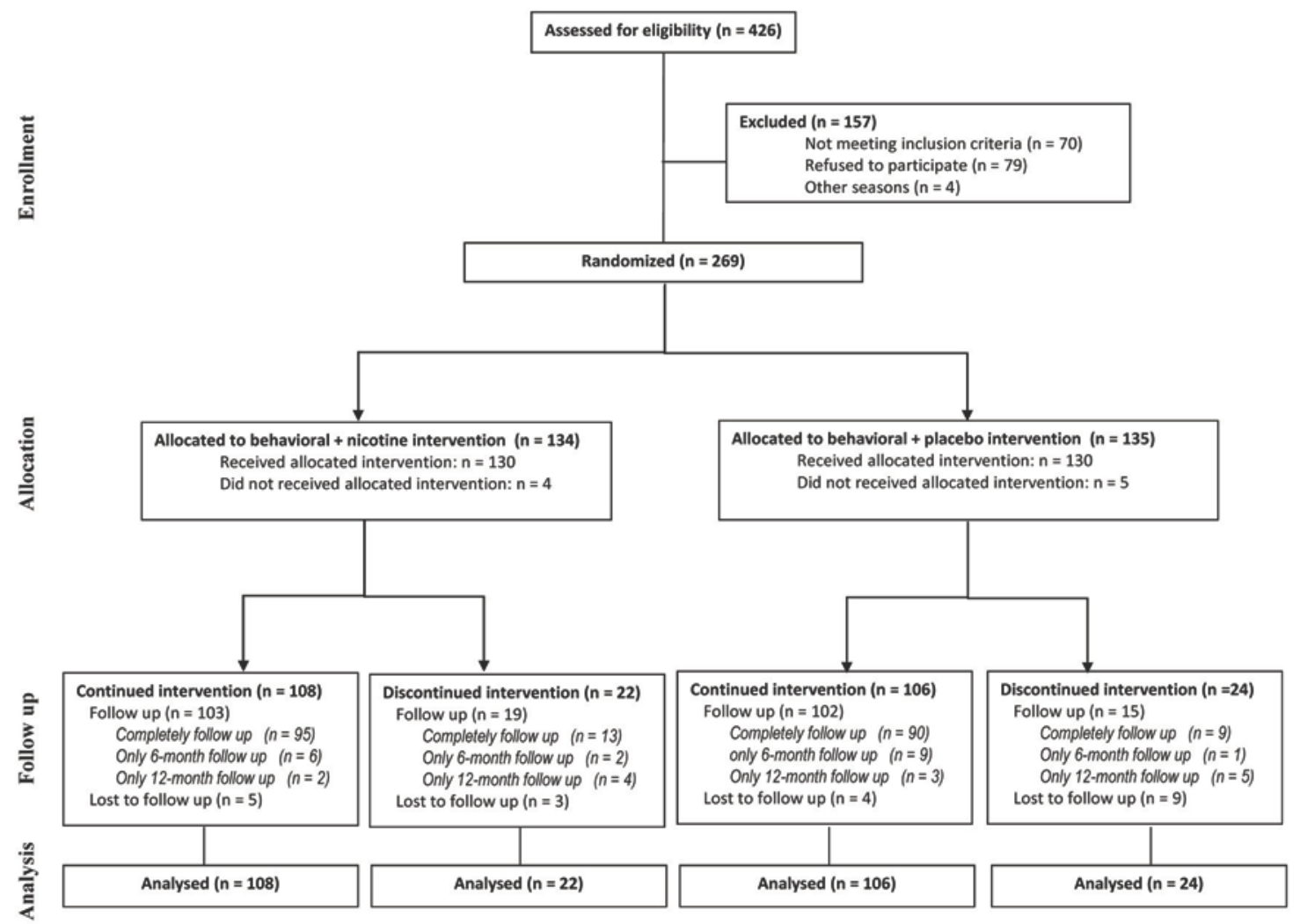

Given evidence generated by the SCTS that many waterpipe smokers exhibit withdrawal and other dependence symptoms and have difficulty quitting, we have argued that efforts are needed to develop and test WTS-specific cessation interventions. ${ }^{65,66} \mathrm{We}$ conducted a pilot, twoarm, parallel group, randomized, open-label RCT to test the efficacy of intensive behavioral treatment for waterpipe smokers who were interested in quitting. We adapted intervention 
strategies from our cigarette trials. ${ }^{57,59}$ Fifty adults who smoked waterpipe three or more times per week for at least one year, did not smoke cigarettes, and were interested in quitting were randomized to receive either brief (one in-person session and three phone calls) or intensive (three in-person sessions and three phone calls) behavioral counseling from a trained physician in a clinical setting. The primary endpoint was prolonged abstinence at three months postcessation, biochemically confirmed. Prolonged abstinence was achieved by $30 \%$ and $44 \%$ of participants in the brief and intensive interventions, respectively. This difference was not statistically significant due to the small number of smokers enrolled in this pilot trial $(p=.31)$, but provided encouraging preliminary evidence of the efficacy of this treatment approach. A growing number of trials are now evaluating behavioral and pharmacological treatment approaches for waterpipe smokers. ${ }^{67-69}$

\section{Successes and Challenges}

Our work in the SCTS has been extremely rewarding, but not without its challenges. On the plus side, the efforts of my dedicated and hard-working colleagues over the past 15 years have allowed us to publish more than 120 peer-reviewed papers, participate in two WHO (World Health Organization) advisories on the waterpipe, be continually funded by NIH as well as several non-U.S. funders, establish Syria's first institutional review board, train numerous researchers throughout the EMR, and receive a WHO Director General Prize and the Hamdan Award for the Best Medical/Research Institute in the Arab World.

Like our successes, our challenges have been numerous. Many of these challenges are common to conducting research in resource-poor environments, ranging from the relatively minor (keeping the electricity on when the grid is unreliable) to the major (how to pay employees a living wage during rampant inflation caused by the influx of Iraqi War refugees, and how to avoid "brain drain" and ensure that researchers have viable career paths).

Other challenges were specific to the tense political environment surrounding U.S./Middle East relationships. Syrians were suspicious of U.S. intentions, and we had to cope with spying, interference from government agencies, and the temporary closing of our center due to false antigovernment activities charges, which required the intervention of the Syrian ambassador to the United States. In theUnited States, there was not much popular support after 9/11 for using tax dollars to conduct research efforts in the Middle East. After the United States enacted sanctions in 2003 to stop Syria's alleged development of weapons of mass destruction, we had to find creative ways to pay our staff and keep our research operation alive. With all these challenges, NIH's tireless support-both financial and in helping us navigate the web of government agencies and resources - was critical to our success.

These problems, however, pale in comparison to those resulting from the Syrian Civil War, which began in 2011 as part of the wider Arab Spring protests throughout the region. We were able to carry on our work in Syria early in the war, but Aleppo finally was engulfed. Beautiful Aleppo, the ancient city on the Silk Road, is now a war zone, and called "the worst place in the world," ${ }^{\prime \prime 0}$ with little food, water, or electricity. Probably at least two-thirds of its population have fled, been forcibly removed, or been killed. Our staff are now dispersed to other countries, and the SCTS continues to thrive as a "virtual” research center. Fortunately, the partnerships the SCTS established have allowed our work to continue despite the horrific situation in Syria. Studies have been conducted in neighboring Jordan ${ }^{71-73}$ and Lebanon. Presently, in Beirut, we are conducting the Waterpipe Dependence in Lebanese Youth (WDLY) prospective study, 
tracking the development of nicotine dependence in a cohort of 498 adolescent cigarette and waterpipe smokers and those susceptible to smoking. Recently published baseline data from the WDLY indicate that nicotine dependence can appear within a relatively short time after initiation, and occurs at a lower frequency of use compared to cigarette smoking. ${ }^{74-76}$

The work of the SCTS continues, and we recently were funded on the fourth round of NIH's International Tobacco Health and Capacity-Building Program (RFA-TW-16-003; 1R01TW010654, W. Maziak, PI). This new project will continue some of our ongoing work, and expand our research partnerships in the region. Our aims are to 1) understand late nicotine dependence trajectories among the WDLY cohort of young waterpipe and cigarette smokers in Lebanon; 2) develop and test waterpipe-specific health warning labels for the Eastern Mediterranean Region using a mixed methods approach; 3) conduct a situational analysis in Tunisia and Lebanon to understand local tobacco control policy environments; and 4) train researchers in Tunisia and Lebanon through a mixture of didactic training and applied mentored research.

Over the past 15 years, we have often cited a Carl Sagan quote that speaks to the backdrop of our work in the SCTS, and this quote seems as relevant as ever in today's turbulent world: "Whenever our ethnic or national prejudices are aroused, in times of scarcity, during challenges to national self-esteem or nerve, when we agonize about our diminished cosmic place and purpose, or when fanaticism is bubbling up around us--then, habits of thought familiar from ages past reach for the controls. The candle flame gutters. Its little pool of light trembles. Darkness gathers. The demons begin to stir." 77 The SCTS is our small attempt to keep the demons from stirring.

\section{Acknowledgements}

This work was supported by US Public Health Service Grants R01 DA035160, R01 TW009266, R01 DA024876 (W. Maziak, PI), and R21 TW006545, R01 TW05962, and R03 TW07233 (K. Ward, PI). I wish to thank my SCTS colleagues: Radwan Al Ali, MD, Taghrid Asfar, MD, MSPH, Iman Ebrahim, BA, Tom Eissenberg, PhD, Madonna Elias, BA, Fouad Fouad, MD, Fadi Hammal, MD, Wasim Maziak, MD, PhD, Fawaz Mzayek, MD, PhD, MPH, and Samer Rastam, $\mathrm{MD}, \mathrm{PhD}$. 


\section{References}

1. Ahn S, Lee J, Bartlett-Prescott J, et al. Evaluation of a behavioral intervention with multiple components among low-income and uninsured adults with obesity and diabetes. Am J Heal Promot. 2017(January):89011711769625. https://doi.org/10.1177/0890117117696250.

2. Niaura R, Todaro JF, Stroud L, et al. Hostility, the metabolic syndrome, and incident coronary heart disease. Health Psychol. 2002;21(6):588-593. https://doi.org/10.1037/0278-6133.21.6.588. 3. Shen B, Todaro JF, Niaura R, et al. Are metabolic risk factors one unified syndrome ? Modeling the structure of the metabolic syndrome X. Am J Epidemiol. 2003;157(8):701-711. https://doi.org/10.1093/aje/kwg045.

4. Spiro A, Aldwin CM, Ward KD, et al. Personality and the incidence of hypertension among older men: longitudinal findings from the Normative Aging Study. Health Psychol. 1995;14(6):563-569.

5. Ward KD, Sparrow D, Landsberg L, et al. The relationship of epinephrine excretion to serum lipid levels: the Normative Aging Study. Metabolism. 1994;43(4):509-513. https://doi.org/10.1016/0026-0495(94)90085-X.

6. Ward KD, Sparrow D, Landsberg L, et al. Influence of insulin, sympathetic nervous system activity, and obesity on blood pressure: the Normative Aging Study. J Hypertens. 1996;14(3):301-308. https://doi.org/10.1097/00004872-199603000-00005.

7. Ward KD, Sparrow D, Vokonas PS, et al. The relationships of abdominal obesity, hyperinsulinemia and saturated fat intake to serum lipid levels: the Normative Aging Study. Int $J$ Obes. 1993;18(3):137-144.

8. Collins AC, Ward KD, McClanahan BS, et al. Bone accrual in children and adolescent nonelite swimmers: a 2-Year longitudinal study. Clin J Sport Sci. 2017;Jul 11. do(0). https://doi.org/10.1097/JSM.0000000000000484.

9. Klesges RC, Ward KD, Shelton ML, et al. Changes in bone mineral content in male athletes: mechanisms of action and intervention effects. JAMA. 1996;276(3):226-230. https://doi.org/10.1001/jama.1996.03540030060033.

10. Ward KD, Klesges RC. A meta-analysis of the effects of cigarette smoking on bone mineral density. Calcif Tissue Int. 2001;68(5):259-270.

11. Mehlenbeck RS, Ward KD, Klesges RC, Vukadinovich CM. A pilot intervention to increase calcium intake in female collegiate athletes. Int J Sport Nutr Exerc. 2004;14(1):18-29. https://doi.org/10.1123/ijsnem.14.1.18.

12. Ward KD, Hunt KM, Berg MB, et al. Reliability and validity of a brief questionnaire to assess calcium intake in female collegiate athletes. Int J Sport Nutr Exerc. 2004;14(2):209-221. https://doi.org/10.1123/ijsnem.14.2.209.

13. Klesges RC, Harmon-Clayton K, Ward KD, et al. Predictors of milk consumption in a population of 17- to 35-year-old military personnel. J Am Diet Assoc. 1999;99(7):821-826. https://doi.org/10.1016/S0002-8223(99)00195-9.

14. Garvey AJ, Ward KD, Bliss RE, et al. Relation between saliva cotinine concentration, cigarette consumption, and blood pressure among smokers. Am J Cardiol. 1995;76(1-2):95-97. https://doi.org/10.1016/S0002-9149(99)80813-3.

15. Ward KD, Klesges RC, Zbikowski SM, et al. Gender differences in the outcome of an unaided smoking cessation attempt. Addict Behav. 1997;22(4):521-533.

https://doi.org/10.1016/S0306-4603(96)00063-9. 
16. Ward KD, Garvey AJ, Bliss RE. Evidence of transient heart rate change after smoking cessation. Psychopharmacology (Berl). 1992;106(3):337-340.

17. Klesges RC, Winders SE, Meyers AW, et al. How much weight gain occurs following smoking cessation? A comparison of weight gain using both continuous and point prevalence abstinence. J Consult Clin Psychol. 1997;65(2):286-291. https://doi.org/10.1037/0022006X.65.2.286.

18. Ward KD, Vander Weg MW, Kovach KW, et al. Ethnic and gender differences in smoking and smoking cessation in a population of young adult air force recruits. Am J Heal Promot. 2002;16(5):259-266.

19. Ward KD, Vander Weg MW, Klesges RC, et al. Characteristics of highly physically active smokers in a population of young adult military recruits. Addict Behav. 2003;28(8):1405-1418. https://doi.org/10.1016/S0306-4603(02)00267-8.

20. Ward KD, Klesges RC, Halpern MT. Predictors of smoking cessation and state-of-the-art smoking interventions. J Soc Issues. 1997;53(1):129-145. http://dx.doi.org/10.1111/00224537.919979.

21. Klesges RC, Ward KD, DeBon MW. Smoking cessation: a successful behavioral/ pharmacologic interface. Clin Psychol Rev. 1996;16(6):479-496. https://doi.org/10.1016/02727358(96)00028-1.

22. Brandt AM. The Cigarette Century: The Rise, Fall, and Deadly Persistence of the Product That Defined America. New York, NY: Basic Books; 2007.

23. Wipfli H, Samet JM. One hundred years in the making: the global tobacco epidemic. Annu Rev Public Heal. 2016;37:149-166. https://doi.org/10.1146/annurev-publhealth-032315-021850. 24. US Department of Health, Education, and Welfare. Smoking and health: a report of the Surgeon General. Washington, DC: US Government Printing Office; 1979.

25. US Department of Health, Education, and Welfare. Smoking and health: report of the Advisory Committee to the Surgeon General of the United States. Washington, DC: US Government Printing Office; 1964.

26. Jamal A, King BA, Neff LJ, et al. Current cigarette smoking among adults — United States, 2005-2015. Morb Mortal Wkly Rep. 2016;65(44):1205-1211.

27. Warner KE. An endgame for tobacco? Tob Control. 2013;22(suppl 1):i3-5. https://doi.org/10.1136/tobaccocontrol-2013-050989.

28. Koppaka, R; Domestic Public Health Achievements Team, CDC. Ten great public health achievements — United States, 2001-2010. Morb Mortal Wkly Rep. 2016;60(19):619-623. 29. Office of Behavioral and Social Sciences Research. Public health achievements of the behavioral and social sciences: improving health at home and abroad. NIH Publication No. 086376; 2008.

30. US Department of Health and Human Services. The health consequences of smoking: 50 years of progress. A report of the Surgeon General. Atlanta, GA: US Department of Health and Human Services, Centers for Disease Control and Prevention, National Center for Chronic Disease Prevention and Health Promotion, Office on Smoking and Health; 2014.

http://www.surgeongeneral.gov/library/reports/50-years-of-progress/full-report.pdf.

31. World Health Organization. WHO report on the global tobacco epidemic, 2015: raising taxes on tobacco. Geneva, Switzerland: World Health Organization; 2015. http://apps.who.int/iris/bitstream/10665/178574/1/9789240694606_eng.pdf?ua=1\&ua=1.

32. Eriksen M, Mackay J, Schluger N, et al. The Tobacco Atlas. 5th ed. Atlanta, GA: American Cancer Society; 2015. 
33. Kluger R. America's Hundred-Year Cigarette War, The Public Health, And The Unabashed Triumph of Philip Morris. New York, NY: Vintage Books; 1996.

34. Vastag B. World health focus of Fogarty International Center. JAMA. 2002;287(16):20632064. https://doi.org/10.1001/jama.287.16.2063-JMN0424-2-1.

35. Maziak W. Smoking in Syria -- profile of a developing Arab country. Int J Tuberc Lung Dis. 2002;6(3):183-191.

36. Maziak W, Ward KD, Afifi Soweid RA, et al. Tobacco smoking using a waterpipe: a reemerging strain in a global epidemic. Tob Control. 2004;13(4):327-333.

http://dx.doi.org/10.1136/tc.2004.008169.

37. Maziak W, Eissenberg T, Rastam S, et al. Beliefs and attitudes related to narghile (waterpipe) smoking among university students in Syria. Ann Epidemiol. 2004;14(9):646-654.

https://doi.org/10.1016/j.annepidem.2003.11.003.

38. Akl EA, Jawad M, Lam WY, et al. Motives, beliefs and attitudes towards waterpipe tobacco smoking : a systematic review. Harm Reduct J. 2013;10(12):1-10. https://doi.org/10.1186/14777517-10-12.

39. Maziak W, Ben Taleb Z, Bahelah R, et al. The global epidemiology of waterpipe smoking. Tob Control. 2015;24(Suppl 1):i3-i12. https://doi.org/10.1136/tobaccocontrol-2014-051903. 40. Akl EA, Ward KD, Bteddini D, et al. The allure of the waterpipe: a narrative review of factors affecting the epidemic rise in waterpipe smoking among young persons globally. Tob Control. 2015;24(Suppl 1):i13-i21. https://doi.org/10.1136/tobaccocontrol-2014-051906.

41. Akl EA, Gaddam S, Gunukula SK, et al. The effects of waterpipe tobacco smoking on health outcomes: a systematic review. Int J Epidemiol. 2010;39(3):834-857.

https://doi.org/10.1093/ije/dyq002.

42. El-Zaatari ZM, Chami HA, Zaatari GS. Health effects associated with waterpipe smoking. Tob Control. 2015;24(Suppl 1):i31-i43. https://doi.org/10.1136/tobaccocontrol-2014-051908. 43. Ward KD, Eissenberg T, Gray JN, et al. Characteristics of U.S. waterpipe users: a preliminary report. Nicotine Tob Res. 2007;9(12):1339-1346.

https://doi.org/10.1080/14622200701705019.

44. Eissenberg T, Ward KD, Smith-Simone S, et al. Waterpipe tobacco smoking on a U.S. college campus: prevalence and correlates. J Adolesc Heal. 2008;42(5):526-529.

https://doi.org/10.1016/j.jadohealth.2007.10.004.

45. Hammal F, Mock J, Ward KD, Eissenberg T, Maziak W. A pleasure among friends: how narghile (waterpipe) smoking differs from cigarette smoking in Syria. Tob Control.

2008;17(2):e3. https://doi.org/10.1136/tc.2007.020529.

46. Hammal F, Mock J, Ward KD, et al. Settling with danger: conditions and health problems in peri-urban neighbourhoods in Aleppo, Syria. Environ Urban. 2005;17(2):113-1265. https://doi.org/10.1177/095624780501700209.

47. Maziak W, Rastam S, Ibrahim I, et al. CO exposure, puff topography, and subjective effects in waterpipe tobacco smokers. Nicotine Tob Res. 2009;11(7):806-811.

https://doi.org/10.1093/ntr/ntp066.

48. Rastam S, Eissenberg T, Ibrahim I, et al. Comparative analysis of waterpipe and cigarette suppression of abstinence and craving symptoms. Addict Behav. 2011;36(5):555-559. https://doi.org/10.1016/j.addbeh.2011.01.021.

49. Maziak W, Rastam S, Shihadeh AL, et al. Nicotine exposure in daily waterpipe smokers and its relation to puff topography. Addict Behav. 2011;36(4):397-399.

https://doi.org/10.1016/j.addbeh.2010.11.013. 
50. Ward KD, Eissenberg T, Rastam S, et al. The tobacco epidemic in Syria. Tob Control. 2006;15(Suppl 1):i24-i29. https://doi.org/10.1136/tc.2005.014860.

51. Rastam S, Ward KD, Eissenberg T, et al. Estimating the beginning of the waterpipe epidemic in Syria. BMC Public Health. 2004;4:32. https://doi.org/10.1186/1471-2458-4-32.

52. Ward KD, Hammal F, VanderWeg MW, et al. Are waterpipe users interested in quitting?

Nicotine Tob Res. 2005;7(1):149-156. https://doi.org/10.1080/14622200412331328402.

53. Maziak W, Ward KD, Eissenberg T. Factors related to frequency of narghile (waterpipe) use: the first insights on tobacco dependence in narghile users. Drug Alcohol Depend. 2004;76(1):101-106. https://doi.org/10.1016/j.drugalcdep.2004.04.007.

54. Maziak W, Eissenberg T, Ward KD. Patterns of waterpipe use and dependence: implications for intervention development. Pharmacol Biochem Behav. 2005;80(1):173-179.

https://doi.org/10.1016/j.pbb.2004.10.026.

55. Asfar T, Al-Ali R, Ward KD, et al. Are primary health care providers prepared to implement an anti-smoking program in Syria? Patient Educ Couns. 2011;85(2):201-205.

https://doi.org/10.1016/j.pec.2010.11.011.

56. Asfar T, Ward KD, Al-Ali R, Maziak W. Building evidence-based tobacco treatment in the Eastern Mediterranean region: lessons learned by the Syrian Center for Tobacco Studies. J Smok Cessat. 2016;11(2):116-123. https://doi.org/10.1017/jsc.2016.5.

57. Asfar T, VanderWeg MW, Maziak W, et al. Outcomes and Adherence in Syria's first smoking cessation trial. Am J Health Behav. 2008;32(2):146-156.

https://doi.org/10.5993/AJHB.32.2.4.

58. Fiore MC; US Public Health Service. The clinical practice guideline for treating tobacco use and dependence: 2008 update. A US Public Health Service Report. Am J Prev Med.

2008;35(2):158-176. https://doi.org/10.1016/j.amepre.2008.04.009.

59. Ward KD, Asfar T, Al Ali R, et al. Randomized trial of the effectiveness of combined behavioral/pharmacological smoking cessation treatment in Syrian primary care clinics. Addiction. 2013;108(2):394-403. https://doi.org/10.1111/j.1360-0443.2012.04048.x. 60. Ben Taleb Z, Ward KD, Asfar T, et al. Predictors of adherence to pharmacological and behavioral treatment in a cessation trial among smokers in Aleppo, Syria. Drug Alcohol Depend. 2015;153:167-172. https://doi.org/10.1016/j.drugalcdep.2015.05.038.

61. Ben Taleb Z, Ward KD, Asfar T, et al. Predictors of nicotine withdrawal symptoms: findings from the first randomized smoking cessation trial in a low-income country setting. Int $J$ Public Health. 2016;61(6):701-708. https://doi.org/10.1007/s00038-016-0818-8.

62. Ben Taleb Z, Ward KD, Asfar T, et al. Smoking cessation and changes in body mass index: findings from the first randomized cessation trial in a low-income country setting. Nicotine Tob Res. 2017;19(3):351-356. https://doi.org/10.1093/ntr/ntw223.

63. Stead LF, Koilpillai P, Fanshawe TR, et al. Combined pharmacotherapy and behavioural interventions for smoking cessation. Cochrane Database Syst Rev. 2016;11(3):1-118. https://doi.org/10.1002/14651858.CD008286.pub3.

64. Stead LF, Perera R, Bullen C, et al. Nicotine replacement therapy for smoking cessation (Review). Cochrane Database Syst Rev. 2012;11(4):1-264. https://doi.org/10.1002/14651858.CD000146.pub4.

65. Lopez AA, Eissenberg T, Jaafar M, et al. Now is the time to advocate for interventions designed specifically to prevent and control waterpipe tobacco smoking. Addict Behav. 2017;66:41-47. https://doi.org/10.1016/j.addbeh.2016.11.008. 
66. Ward KD, Siddiqi K, Ahluwalia JS, et al. Waterpipe tobacco smoking: the critical need for cessation treatment. Drug Alcohol Depend. 2015;153:14-21.

https://doi.org/10.1016/j.drugalcdep.2015.05.029.

67. Jawad M, Jawad S, Waziry RK, et al. Interventions for waterpipe tobacco smoking prevention and cessation: a systematic review. Sci Rep. 2016;6:25872.

https://doi.org/10.1038/srep25872.

68. Maziak W, Eissenberg T, Klesges R, et al. Adapting smoking cessation interventions for developing countries: a model for the Middle East. Int J Tuberc Lung Dis. 2004;8(4):403-413. 69. Maziak W, Jawad M, Jawad S, et al. Interventions for waterpipe smoking cessation (Review). Cochrane Database Syst Rev. 2015;7(3):1-25. https://doi.org/10.1002/14651858.CD005549.pub3.

70. Hamdo AH, Osman T. Violence, loyalty keep people of Aleppo, Syria in "worst place in the world.” United Press International. https://www.upi.com/Top_News/WorldNews/2016/05/06/Violence-loyalty-keep-people-of-Aleppo-Syria-in-worst-place-in-theworld/7991462459024/. Published May 6, 2016. Accessed July 31, 2017.

71. Jaber R, Mzayek F, Madhivanan P, et al. Predictors of cigarette smoking progression among a school-based sample of adolescents in Irbid, Jordan: a longitudinal study (2008-2011). Nicotine Tob Res. 2016;18(4):403-409. https://doi.org/10.1093/ntr/ntv100.

72. Mzayek F, Khader Y, Eissenberg T, et al. Patterns of water-pipe and cigarette smoking initiation in schoolchildren: Irbid longitudinal smoking study. Nicotine Tob Res. 2012;14(4):448454. https://doi.org/10.1093/ntr/ntr234.

73. Alzoubi KH, Khabour OF, Azab M, et al. CO exposure and puff topography are associated with Lebanese Waterpipe Dependence Scale score. Nicotine Tob Res. 2013;15(10):1782-1786. https://doi.org/10.1093/ntr/ntt049.

74. Bahelah R, DiFranza JR, Ward KD, et al. Correlates of nicotine dependence among adolescent waterpipe smokers. Drug Alcohol Depend. 2016;168:230-238. https://doi.org/10.1016/j.drugalcdep.2016.09.019.

75. Bahelah R, DiFranza JR, Ward KD, et al. Waterpipe smoking patterns and symptoms of nicotine dependence: the Waterpipe Dependence in Lebanese Youth Study. Addict Behav. 2017;74(June):127-133. https://doi.org/10.1016/j.addbeh.2017.06.003.

76. Bahelah R, DiFranza JR, Fouad FM, et al. Early symptoms of nicotine dependence among adolescent waterpipe smokers. Tob Control. 2016;25:e127-e134. https://doi.org/10.1136/tobaccocontrol-2015-052809.

77. Sagan C. The Demon-haunted World: Science as a Candle in the Dark. New York, NY: Ballantine Books; 1997. 